\title{
Guest Editorial: East to West-Agricultural Origins and Dispersal into Europe
}

\section{Citation}

Bar\#Yosef, Ofer. 2004. Guest Editorial: East to West-Agricultural Origins and Dispersal into Europe. Current Anthropology 45, no. S4: S1-S3.

\section{Published Version}

doi:10.1086/423970

\section{Permanent link}

http://nrs.harvard.edu/urn-3:HUL.InstRepos:12242825

\section{Terms of Use}

This article was downloaded from Harvard University's DASH repository, and is made available under the terms and conditions applicable to Other Posted Material, as set forth at http:// nrs.harvard.edu/urn-3:HUL.InstRepos:dash.current.terms-of-use\#LAA

\section{Share Your Story}

The Harvard community has made this article openly available.

Please share how this access benefits you. Submit a story.

Accessibility 


\section{Guest Editorial: East to West-Agricultural Origins and Dispersal into Europe}

The transition from foraging to farming and herding was a major socioeconomic and cultural revolution that imprinted human collective memory, becoming synonymous with the human "childhood's end" or, as narrated in the Bible, humans' expulsion from the Garden of Eden. Not surprisingly, since the mid-nineteenth century, with the advent of scientific investigations of prehistoric sites, each successive generation of historians and archaeologists has contributed data and interpretations to our rapidly accumulating record on the origins of agriculture. The four papers in this issue, likewise, add new and revised data on the origin and dispersal of farming from the Mediterranean Levant into western Europe.

In any investigation, confirming the when and where of a socioeconomic transition precedes the critical question of why it occurred. Increasing numbers of excavations in southwestern Asia and Europe over the past two decades (though some crucial geographical regions still remain terra incognita) have generated a wealth of information about the lifeways of the last foragers and the first farmer-herders. Progress in the calibration of radiocarbon dates to calendrical years (still applied sporadically by many archaeologists) facilitates reliable chronologies for sequencing major socioeconomic shifts and their presumed tempo and stages. Therefore the early cultivation of founder crops, plant domestication, wild animal penning, herding, and the ensuing morphometric changes in domesticated species, episodes or waves of island colonization, and the dispersal of human groups and technologies throughout the European continent are now more reliably dated than before. Equally striking are the contributions of scientific and genetic research techniques (e.g., studies of strontium isotopes, ancient DNA, the current distribution of mtDNA, Y-chromosome lineages, etc.), though the interpretations of the results are sometimes controversial. The ambiguous correlation between various domains of research such as genetics, archaeology, and linguistics has been undertaken by many and led to a series of interesting conferences (e.g., Renfrew and Boyle 2000, Bellwood and Renfrew 2002).

The baseline for reconstructing the history of early farming begins with the local foragers, some of whom were the "forefathers" of the Neolithic Revolution. Natalie Munro's paper in this issue on Levantine Natufian subsistence presents an archaeozoological background for a plausibly formulated sequence of events leading to intentional cultivation by providing information concerning the depletion of animal-tissue resources during the Younger Dryas (I 3,000-I I, 600 cal BP) in the southern Levant. During this cold and dry period, which terminated the Pleistocene, the previously flourishing semisedentary Early Natufian society (I 4,500-I 3,000 cal BP [Belfer-Cohen and Bar-Yosef 2000]) adopted a more mobile settlement pattern of smaller groups. This change is indicated by the increased consumption of low-ranked resources such as bone grease, juvenile gazelles, and fastmoving small game such as hares. While the exact timing and context of intentional cultivation cannot be detected from the faunal remains, detailed analysis reveals that Late Natufian groups were responding to the onset of stressful environmental conditions. In this chronological context, we may note that the shortage of extensive field research for contemporaneous Late Pleistocene foragers in southeastern Turkey-geographically part of the northern Levant-hampers a full assessment of the impact of encroaching arid conditions on endemic hunter-gatherers. The sole example of Hallan Çemi, a Late Paleolithic village situated on a Tigris River tributary (Rosenberg and Redding 2000) and radiocarbondated to the Younger Dryas, indicates that sedentism as a social mechanism for the control of resources was one option adopted by local groups. Although Hallan Çemi is located on the eastern fringes of the region, it may support Colledge et al.'s suggestion in this issue that humans initiated intentional cultivation in reaction to worsening climatic conditions, an interpretation suggested earlier (Bar-Yosef and Belfer-Cohen 2002, Wright and Thorpe 2003).

Colledge et al. refer to numerous published archaeobotanical assemblages from the Near East (including Greece), while recognizing the limitations of these data sets because of retrieval techniques and taphonomic issues, in order to identify the "crop package" of Near Eastern early farmers. This suite of crops was carried by Neolithic farmers on their migration routes into the mainland as well as to Cyprus and Greece. Colledge et al. discuss the evidence for a short or a long gestation period for the domestication process. Whether its gestation was long or short, the length of time required to transform the majority of the annuals, particularly the cereals, into species with nonshattering rachises remains unknown. Hillman and Davies (I992) suggest 20 to 200 years, while Kislev (I 997) proposes I, 000 years (the duration of the PrePottery Neolithic A, ca. I I,600-10,500 cal BP). Colledge et al., on the basis of earlier work (Colledge I998), prefer the first hypothesis and view the archaeobotanical evidence from the PPNA sites along the Levantine corridor as reflecting rapid adoption of the cultivation of wild cereals. Most scientists agree that by the Early or Middle PPNB (ca. I0,500-9000 cal BP) most Neolithic villages enjoyed some domesticated crops.

The evidence for early migrations and/or colonizations is stronger today because of recent discoveries in Early/ Middle PPNB sites in Cyprus. Goat, sheep, pig, and cattle, according to morphometrics not yet domesticated, as well as dog, cat, and fallow deer, were transported from the coast of Anatolia to Cyprus (Vigne 200I, Vigne et al. 2004). This means that a long period of penning and tend- 
ing took place on the mainland. Quite possibly the same processes applied to plants as well. Moreover, the hypothesis of "long gestation" is supported by recently published evidence that ground collection of seeds was feasible for early cultivators and may have been practiced for a prolonged period (Kislev, Weiss, and Hartmann 2004). This observation reopens the question of how the flint sickles bearing evidence for cutting cereals were actually employed. Perhaps earlier proposals that the $\mathrm{Na}$ tufian sickles were used to procure reeds and straw for constructing thatched walls and roofs should be scientifically tested. In contrast to the domestic structures of the PPNA and PPNB, these pit houses contained no accumulation of mudbricks and wattle and daub.

Most scholars agree that the "founder crops" or the limited "farming package" (including a smaller number of weeds) imported to the islands and Greece were accompanied by other material culture markers reflecting colonization by migrant groups (e.g., Perlès 200I). Supporting evidence is provided by Y-chromosome lineages (King and Underhill 2002) that demonstrate the same geographic trajectory as proposed by Ammerman and Cavalli-Sforza (I984; for a historical review see CavalliSforza 2002). This demic diffusion or "wave of advance" is a generalized term on a continental scale but at the regional level incorporates "saltatory jumps" as defined by van Andel and Runnels (I995; Bar-Yosef 2002; CavalliSforza 2002).

The article by Pinhasi and Pluciennik provides another angle on population dispersals into Europe based on craniometric analyses of several Epipaleolithic, Mesolithic, and Neolithic samples from the Levant, Anatolia, and Europe. Their table I shows the variable sizes of the samples as well as the chronological and geographic gaps. Employing a principal components analysis, they reduce the number of variables and then search for differences between populations through a discriminant analysis. While in the Levant the time gap between the Natufian (mostly from the early period) and the PPNB is at least 2,500 years, the European specimens are closer to each other in time. The observation that the Natufian population was different from contemporary foragers in Europe leads to further conclusions. Indeed, consistent with the proposal that the Anatolian farmers moved relatively rapidly into Europe, the researchers find clear differences between the late Upper Paleolithic and Mesolithic Europeans and those of the early Neolithic. As an example, Pinhasi and Pluciennik show a similarity between the Çatal Höyük specimens and those of southeastern Europe. Thus the emerging picture posits the same questions concerning migrations and acculturations as have been discussed for the past three decades. With the advent of population genetics, researchers seek the relationship between modern gene frequencies, prehistoric material culture, human remains, and languages (Renfrew and Boyle 2000, Bellwood and Renfrew 2002). When these aspects are translated into daily, annual, or decadal human behavior and inter- and intragroup interactions, scientists must consider the time required to move across a landscape (be it rugged, a flat plain, or a river valley) before draft animals were available. Transport by sea was already being employed, as the evidence for the Cypriote Epipaleolithic indicates (Simmons I999). At the same time, transporting seeds (in baskets or woven bags?) into a new territory, encountering foragers who speak a different language, the role of leaders, and the like, highlight the intricate cultural and genetic puzzle created by human agency.

Archaeological field and laboratory investigations are conducted in the zealous effort to know more. Therefore, presenting the big picture as we do on an almost yearly basis depends on access to newly acquired data sets, particularly in a region where reports are published in local languages. In this respect, the paper by Rowley-Conwy in this issue clearly shows that the information accumulated during the past 15 years in northwestern Europe yields a different scenario from the one commonly accepted at present. Rather than the gradual establishment of agricultural subsistence economy, in Ireland, Britain, and southern Scandinavia the process was a "revolution."

From a historical viewpoint, the focus on archaeological regional studies in the framework of cultural ecology developed in the r960s and I970s resulted in the rejection of the notion that people moved as groups. Migration and colonization became unacceptable explanations for archaeological observations. Only later did Anthony (I990), in a seminal paper, restore the subject to the forefront of the archaeological debate at the same time as genetic investigations were having a major impact on archaeological issues. With the application of analytical techniques (e.g., strontium isotope analysis, as mentioned above), methods for testing human dispersal are being developed. The evidence from the central and western Mediterranean coasts supports the interpretation of population expansions representing probably more than one wave. The trigger for such "saltatory jumps" could have been depletion of local resources. Holocene climatic fluctuations at both ends-the eastern Mediterranean and Ireland (e.g., Rohling et al. 2002, McDermott, Mattey, and Hawkesworth 200I)-show that certain pulses of colonization were triggered by rapid environmental change and the need to look for new arable lands.

As mentioned by Rowley-Conwy, the idea that foragers made a seamless, gradual transition to farming is unrealistic and has no sound evidence to support it. The dichotomy between Mesolithic hunting-and-gathering lifeways and sedentary Neolithic agriculture is not imaginary but real. A shift in economy or realignment of subsistence strategy is and was a catalyst for social and ideological changes. Without diminishing the role of ideology in any given society, whether hunter-gatherers or early farmers, the archaeological evidence for the evolution of complex social systems is reflected in resource allocation for the construction of public buildings for meetings and/or worship uncovered in recent years in southeastern Turkey and Anatolia (Özdoğan and Basğelen 1999). This means that food security was achieved during the PPNB. The vividly expressed symbols, whether modeled skulls, bucrania, mobile clay and stone 
figurines, painted house walls, individual stone sculptures, stelae, and T-shaped $(3.5-\mathrm{m}$ tall) sculpted and engraved limestone columns provide a wealth of information for fascinating explanations. This richness stands in stark contrast to the meager inventory of symbolic components prior to the emergence of intentional cultivation, which probably indicates that the symbolic revolution resulted from the social and economic change rather than being its catalyst. In addition, population increase among farmers in spite of the vagaries of living together in a constrained and sedentary environment (rather than enjoying annual cycles of mobility within a region) necessitated expansion and resulted in the establishment of new communities. However, when radiocarbon-dated short-lived samples such as seeds are available, "leapfrog" dispersals cannot be traced within a short distance. In the same vein, McDonald's restaurants across the world would be dated as \pm 50 years and would be assumed by future archaeologists to be evidence for contemporaneous emergence. The same impression arises from the archaeological evidence, given the difficulties encountered with the samples provided for radiocarbon dating. It is only when we consider geographic distances on the order of $300-500 \mathrm{~km}$ that dispersals from a "core area" can be traced. This is what is demonstrated in the papers collected in this issue.

\section{OFER BAR-YOSEF}

\section{References Cited}

AMMERMAN, A. J., AND L. L. CAVALLI-SFORZA. I 984 The Neolithic transition and the genetics of populations in Europe. Princeton: Princeton University Press.

ANTHONY, D. W. I990. Migration in archaeology: The baby and the bathwater. American Anthropologist 92:895-9I4.

B A R - Y OSEF, O. 2002. "The Natufian culture and the Early Neolithic: Social and economic trends in southwestern Asia," in Examining the farming/language dispersal hypothesis. Edited by P. Bellwood and C. Renfrew, pp. I I3-26. Cambridge: McDonald Institute for Archaeological Research.

BAR-YOSEF, O., AND A. BELFER-COHEN. 2002. "Facing environmental crisis. Societal and cultural changes at the transition from the Younger Dryas to the Holocene in the Levant," in The dawn of farming the Near East, vol. 6, Studies in early Near Eastern production, subsistence, and environment. Edited by R. T. J. Cappers and S. Bottema, pp. 55-66. Berlin: Ex Oriente.

BELFER-COHEN, A., AND O. BAR-YOSEF. 2000. "Early sedentism in the Near East: A bumpy ride to village life," in Life in Neolithic farming communities: Social organization, identity, and differentiation. Edited by I. Kuijt, pp. 19-37. New York: Plenum Press.

BELLW O OD, P., AND C. RENFREW. Editors. 2002. Examining the farming/language dispersal hypothesis. Cambridge: McDonald Institute for Archaeological Research.

C A VALLI-SFORZA， L. 2002. "Demic diffusion as the basic process of human expansions," in Examining the farming/language dispersal hypothesis. Edited by P. Bellwood and C. Ren- frew, pp. 79-88. Cambridge: McDonald Institute for Archaeological Research.

C OLLEDGE, S. I998. "Identifying pre-domestication cultivation using multivariate analysis," in The origins of agriculture and crop domestication. Edited by A. B. Damania, J. Valkoun, G. Willcox, and C. O. Qualset, pp. I2 I-3 I. Aleppo, Syria: ICARDA.

HILlMAN, G. C., AND M. S. DAvies. I992. "Domestication rate in wild wheats and barley under primitive cultivation: Preliminary results and the archaeological implications of field measurements of selection coefficient," in Préhistoire de l'agriculture. Edited by P. C. Anderson-Gerfaud, pp. I I9-58. Paris: CNRS.

KING, R., AND P. UNDERHILL . 2002. Congruent distribution of Neolithic painted pottery and ceramic figurines with Ychromosome lineages. Antiquity 76:707-I4.

K I S L E V, M. E. I997. "Early agriculture and paleoecology of Netiv Hagdud," in An Early Neolithic village in the Jordan Valley, pt. I, The archaeology of Netiv Hagdud. Edited by O. Bar-Yosef and A. Gopher, pp. 209-36. Cambridge: Peabody $\mathrm{Mu}-$ seum of Archaeology and Ethnology, Harvard University.

KISLEV, M. E., E. WEIS , AND A. HARTMANN. 2004. Impetus for sowing and the beginning of agriculture: Ground collecting of wild cereals. Proceedings of the National Academy of Sciences, U.S.A. IOI:2692-95.

MC DERMOTT, F., D. P. MATTEY, AND C. HAWKESWORTH. 2OOI. Centennial-scale Holocene climate variability revealed by high-resolution speleothem $\mathrm{d}^{18} \mathrm{O}$ record from $\mathrm{SW}$ Ireland. Science 294: I 328-3 I.

ÖZDOĞAN, M., AND N. B AS ĞELEN. Editors. I999. NeOlithic in Turkey: The cradle of civilization, new discoveries. Istanbul: Arkeoloji ve Sanat Yayinlari.

PE RL È , C. 200I. The Early Neolithic of Greece. Cambridge: Cambridge University Press.

RENFREW, C., AND K. BOYLE. 2000. Archaeogenetics: DNA and the population prehistory of Europe. Cambridge: McDonald Institute for Archaeological Research.

ROHLING, E. J., J. CASFORD, R. ABU-ZEID, S. COOKE, D. MERCONE, J. THOMSON, I. CROUDACE, F. J. JORISSEN, H. BRINKHUIS, J. KALLMEYER, AND G. WEFER. 2002. "Rapid Holocene climate changes in the eastern Mediterranean," in Droughts, food, and culture: Ecological change and food security in Africa's later prehistory. Edited by F. A. Hassan, pp. 35-46. New York: Kluwer Academic/Plenum Publishers.

ROSENBERG, M., AND R. W. REDDING. 2000. "Hallan Çemi and early village organization in eastern Anatolia," in Life in Neolithic farming communities: Social organization, identity, and differentiation. Edited by I. Kuijt, pp. 39-6I. New York: Plenum Press.

S I M MONS, A. H. I999. Faunal extinction in an island society. New York: Kluwer Academic/Plenum Publishers.

VAN ANDEL, T., AND C. N. RUNNELS. I995. The earliest farmers in Europe. Antiquity 69:484-500.

VIGNE, J . - D . 2OOI. "Large mammals of early Aceramic Neolithic Cyprus: Preliminary results from Parekklisha Shillourokambos," in The earliest prehistory of Cyprus: From colonization to exploitation, vol. 2(5). Edited by S. Swiny, pp. 55-6o. Boston: Cyprus American Archaeological Research Institute Monograph Series, American Schools of Oriental Research.

VIGNE, J.-D., J. GUILAINE, K. DEBUE, L. HAYE, AND P. GÉRARD. 2004. Burials in Cyprus suggest cats were ancient pets. Science 304:259.

WRIGHT, J. H. E., AND J. L. ThORPE. 2003. "Climatic change and the origin of agriculture in the Near East," in Global change in the Holocene. Edited by A. Mackay, R. W. Battarbee, J. Birks, and F. Oldfield. London: Arnold. 